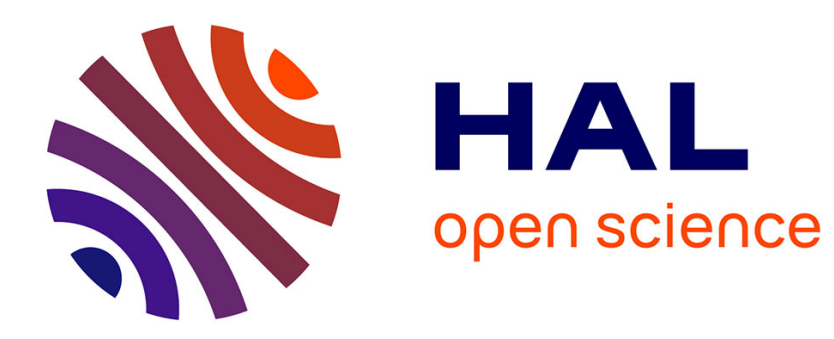

\title{
Polyacetylene thin film photovoltaic devices
}

\author{
M. Cadene, M. Rolland, M. J. M. Abadie
}

\section{To cite this version:}

M. Cadene, M. Rolland, M. J. M. Abadie. Polyacetylene thin film photovoltaic devices. Revue de Physique Appliquée, 1983, 18 (11), pp.691-694. 10.1051/rphysap:019830018011069100 . jpa00245132

\section{HAL Id: jpa-00245132 https://hal.science/jpa-00245132}

Submitted on 1 Jan 1983

HAL is a multi-disciplinary open access archive for the deposit and dissemination of scientific research documents, whether they are published or not. The documents may come from teaching and research institutions in France or abroad, or from public or private research centers.
L'archive ouverte pluridisciplinaire HAL, est destinée au dépôt et à la diffusion de documents scientifiques de niveau recherche, publiés ou non, émanant des établissements d'enseignement et de recherche français ou étrangers, des laboratoires publics ou privés. 


\title{
Polyacetylene thin film photovoltaic devices
}

\author{
M. Cadene ( ${ }^{1}$ ), M. Rolland ( ${ }^{1}$ ) and M. J. M. Abadie ( $\left.{ }^{2}\right)$ \\ ( $\left.{ }^{1}\right)$ Groupe de Dynamique des Phases Condensées \\ $\left({ }^{2}\right)$ Laboratoire de Chimie Macromoléculaire \\ USTL, place E. Bataillon, 34060 Montpellier Cedex, France
}

(Reçu le 4 mars 1983, révisé le 24 juin, accepté le 21 juillet 1983)

\begin{abstract}
Résumé. - Des dispositifs photovoltaïques ont été fabriqués par polymérisation directe de films minces de polyacétylène dopé ou non dopé sur une lame mince polycristalline de CdS déposée sur verre conducteur. La morphologie du contact est déterminée par microscopie à balayage. Les caractéristiques électriques ont été obtenues à l'obscurité et sous éclairement. Dans des conditions standard (AMl, $100 \mathrm{~mW} / \mathrm{cm}^{2}$ ), les hétérojonctions entièrement couches minces à base de $(\mathrm{CH})_{x}$ dopé atteignent un rendement de $0,5 \%$.
\end{abstract}

Abstract. - Photovoltaic devices have been obtained by a direct polymerization of undoped (or p-type doped) thin film $(\mathrm{CH})_{x}$ layer onto a polycrystalline cadmium sulfide film. The morphology of the contact is observed by S.E.M. microscopy. The electrical characteristics of this device are studied in the dark or under illumination. The main result, at AMl, $100 \mathrm{~mW} / \mathrm{cm}^{2}$ with doped $(\mathrm{CH})_{x}$ correspond to 0.5 percent efficiency.

\section{Introduction and sample preparation.}

Polyacetylene has generated considerable interest over the past few years, specially when it was shown that this material could be doped by numerous dopant species, leading to $\mathrm{p}$ or n-type semi-conductor material, or, at high doping level, to an inexpensive polymeric conductor. Its electrical conductivity ranges from $10^{-9} \Omega^{-1} \mathrm{~cm}^{-1}$, if undoped, and reaches $10^{3} \Omega^{-1} \mathrm{~cm}^{-1}$ when $\mathrm{AsF}_{5}$-doped. When undoped or lightly doped, trans $(\mathrm{CH})_{x}$ appears to be a direct band gap p-type semiconductor. Those optical and

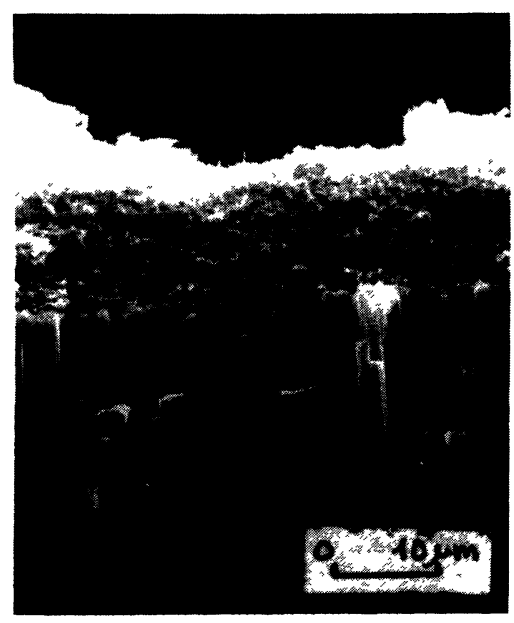

Fig. 1. - Cross section of CdS- $(\mathrm{CH})_{x}$ junction. REVUE DE PHYSIQUE APPLIQUÉE. - T. 18, No 11 electrical properties (absorptivity $\alpha>10^{5} \mathrm{~cm}^{-1}$, optical band gap around $1.5 \mathrm{eV}$, conductivity of the doped material about $10^{2} \Omega^{-1} \mathrm{~cm}^{-1}$ ) seems very interesting for the solar energy photovoltaic conversion. Different $\mathrm{p}-\mathrm{n}$ heterojunction devices have been fabricated by a direct polymerization of an undoped $(\mathrm{CH})_{x}$ thin film onto an n-type single crystal substrate (silicon, gallium arsenide [1], cadmium sulfide [2]) Schottky diodes were obtained by evaporation of a metal transparent layer onto a thick $(\mathrm{CH})_{x}$ film [3] or using high doped material $\left(\mathrm{CH} \mathrm{A}_{y}\right)_{x}$ as metallic electrode on a variety of n-type semiconductors [4]. Such devices are not low cost because they use single crystals. In order to lower the price of the device we realized thin film heterojunction using $(\mathrm{CH})_{x}$ and $\mathrm{CdS}$ polycrystalline layers.

Cadmium sulfide film, 10 to $30 \mu \mathrm{m}$ thick, were obtained by thermal evaporation onto a conducting glass substrate heated at $200^{\circ} \mathrm{C}$. The deposit velocity is about $1 \mu \mathrm{m} . \mathrm{min}^{-1}$. The polycrystalline hexagonal layer present columnar structure with the $c$-axis oriented perpendicular to the substrate. The crystallite diameter is about $2-3 \mu \mathrm{m}$ as shown by S.E.M. microscopy (Fig. 1). On this layer, we directly polymerized acetylene by including them in a glass vessel. The polymerization is performed by the Ito et al. technique [5] in the following experimental conditions : acetylene pressure 1 atmosphere, catalyzer ratio $\mathrm{Al} / \mathrm{Ti}=4, \mathrm{AlEt}_{3}$ concentration $0.2 \mathrm{~mole} / 1$ of 
solvant (toluene), reaction temperature $-78^{\circ} \mathrm{C}$. The $(\mathrm{CH})_{x}$ thickness from 1 to $5 \mu \mathrm{m}$ depends on the duration of the acetylene admission. Before doping. the trans stable isomer is obtained by thermal treatment under vacuum at $140^{\circ} \mathrm{C}$ during five minutes.

The surface aspect of the $(\mathrm{CH})_{x}$ side is showed in figure 2 .

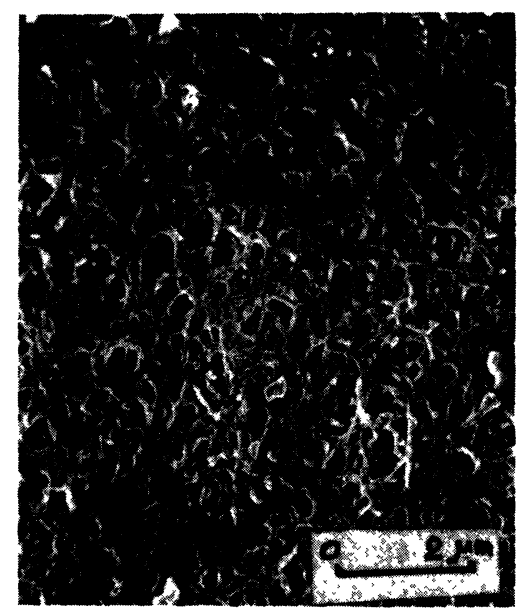

Fig. 2. - Viewgraph of the fibrilar $(\mathrm{CH})_{x}$ surface.

Various dopant species were used to obtain the metallic polymer, for example $\mathrm{I}_{2}, \mathrm{MoCl}_{5}$. The morphology depends strongly of the dopant specie and the doping process [6].

\section{Device characterization.}

The more interesting and performing device is obtained when we use indium tin oxide contact and electrodag +502 onto respectively $\mathrm{CdS}$ and polymer layers (Fig. 3). The backwall illumination by the CdS with its bandgap of $2.4 \mathrm{eV}$ (window material) allows the use of opaque thick $(\mathrm{CH})_{x}$ films and limits the possibility of pinhole shorts.

Good rectifying junctions were always obtained, particularly with undoped material. To characterize the device we used firstly two electrical methods related to the morphology study by S.E.M. microscopy : current versus voltage and capacitance versus

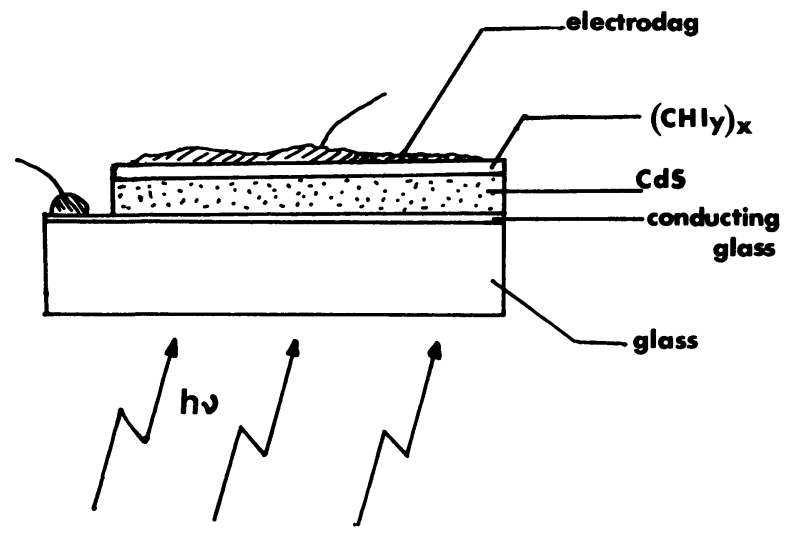

Fig. 3. - Photovoltaic device $\mathrm{CdS} /\left(\mathrm{CHA}_{y}\right)_{x}$. voltage measurements at different temperatures. $C$ - $V$ measurements were made over the frequency range $500 \mathrm{~Hz}$ to $100 \mathrm{kHz}$.

2.1 DARK $J-V$ Characteristics. - The dark $J-V$ characteristics of the cell in the forward direction follows the current-voltage relation-ship well known in Schottky barrier of inorganic semiconductors

$$
J=J_{\mathrm{s}}\left(\exp \frac{q\left(V-R_{\mathrm{s}} J\right)}{n k T}-1\right)
$$

$n$ is the diode quality factor. For $q V / k T \gg 1, \mathrm{Ln} J$ versus $V$ curve is expected to be linear with an intercept corresponding to $J_{\mathbf{s}}$.

2.1.1 Undoped $(\mathrm{CH})_{x}$-CdS junction. - The built-in potential estimated from the extrapolation of the straight portion of the $J-V$ curve is around $0.80 \mathrm{eV}$.

The saturation current density ranges between 0.1 to $1 \mu \mathrm{A} / \mathrm{cm}^{2}$. The coefficient $n$, about 3 to 4 greatly deviates from ideality. At large forward bias, the curve is in good agreement with the resistivity of the undoped trans- $(\mathrm{CH})_{x}$. The series resistance is around $1500 \Omega \cdot \mathrm{mm}^{-2}$.

Figure 4 shows the forward biased $J-V$ characteristics as a function of temperature. The slope $\mathrm{dLn} J / \mathrm{d} V$ is pratically temperature independent and the $J_{\mathrm{s}}$ dependence is weaker than would be predicted by the expression $J_{\mathrm{s}}=A^{*} T^{2} \exp \left(-q \Phi_{\mathrm{B}} / k T\right)$. The simple thermoionic emission model of current transport is not sufficient. However from this expression with $A^{*}=232 \times 10^{3} \mathrm{~A} / \mathrm{m}^{2} \cdot \mathrm{K}^{2}$ for $\mathrm{CdS}$, we obtain at room temperature an approximative value $\Phi_{\mathrm{B}}=0.85 \mathrm{eV}$, in good agreement with the barrier height given by $J-V$ and $C-V$ characteristics.

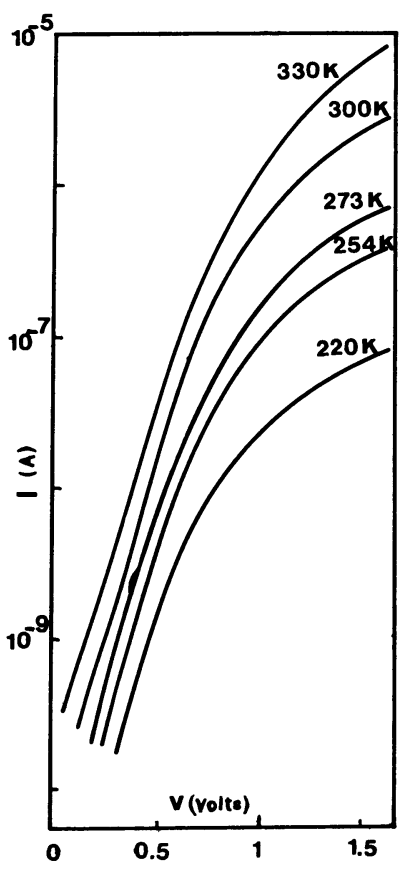

Fig. 4. - Dark $\log J=f(V)$ curves at various temperatures (undoped cell) (surface $0.1 \mathrm{~cm}^{2}$ ). 
2.1.2 Doped $(\mathrm{CH})_{x}$-CdS junction. - The dark current density is more important around $1 \mathrm{~mA} . \mathrm{cm}^{-2}$, the series resistance decreases to $100 \Omega / \mathrm{mm}^{2}$. The built-in potential decreases around $0.70 \mathrm{eV}$. The quality factor $n$ is unchanged.

The linear dependence of $\log J$ versus $V$ is well verified for all temperatures between 80 and $300 \mathrm{~K}$. The slope $\mathrm{dLn} J / \mathrm{d} V$ is not temperature independent. Using the same value of effective Richardson constant $A^{*}$ for CdS resulted in an estimate of $0.68 \mathrm{eV}$ at room temperature for the built-in potential in good agreement with the $J-V$ determination.

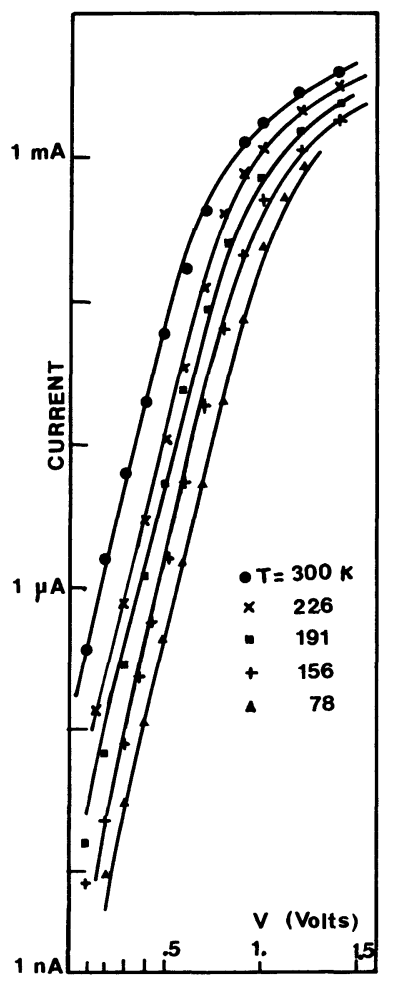

Fig. 5. - Dark $\log J=f(V)$ curves at various temperature (doped cell) (surface $0.1 \mathrm{~cm}^{2}$ ).

2.2 CAPACITANCE - VOLTAGE CHARACTERISTICS. The $C-V$ data for a $(\mathrm{CH})_{x}-\mathrm{CdS}$ thin film heterojunction at different frequencies over the range 1 to $20 \mathrm{kHz}$ are shown in figure 6 . One finds a built-in potential $V_{\mathrm{D}} \approx 1$ volt for undoped cell, and quasi uniform carrier density in the depletion region. The frequency dependence is certainly related to the relaxation time of the deep centres lying in the forbidden gap.

When the cell is degraded, for example by oxygen exposure, the variation $1 / C^{2}=f(V)$ is more complicated showing a non uniform carrier density in the depletion region.

2.3 Photovoltaic behaviour. - The photocurrentphotovoltage characteristics under simulated white constant illumination were shown figures 7 and 8 for undoped or doped cells. Under AM1 illumination

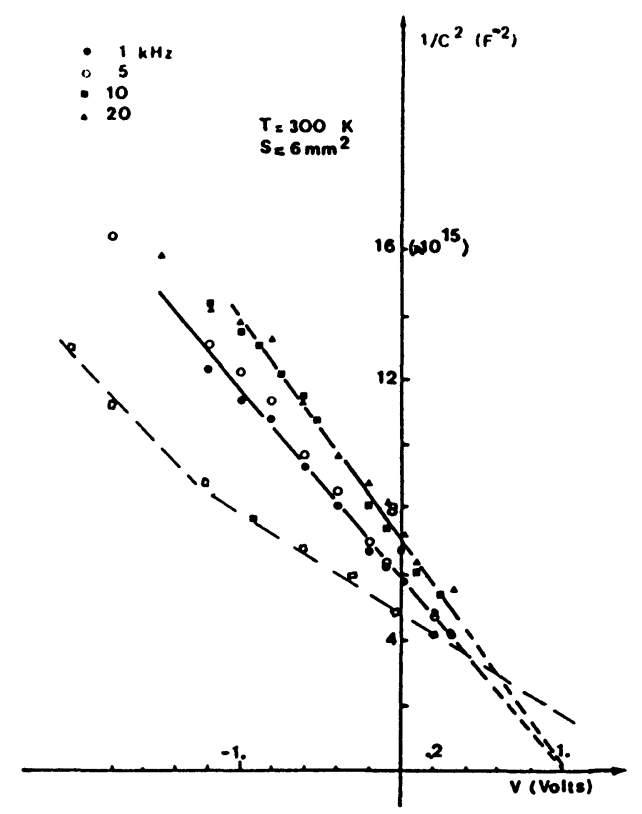

Fig. 6. - Capacitance versus voltage characteristics (-) typical cell, (...) degraded cell.

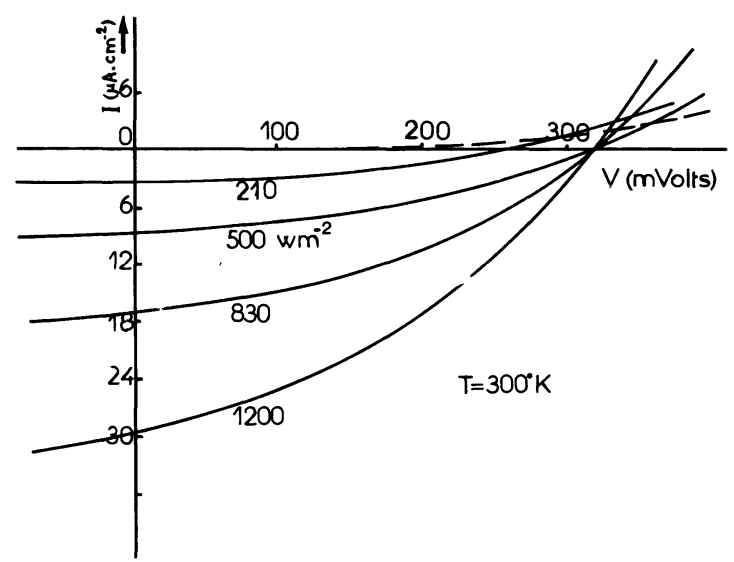

Fig. 7. - J-V characteristics under illumination of the CdS-undoped $(\mathrm{CH})_{x}$ cell (surface $0.1 \mathrm{~cm}^{2}$ ).

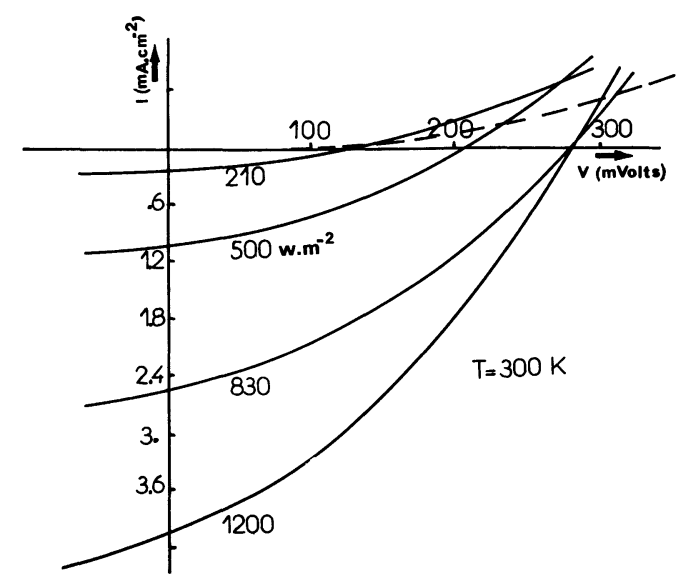

Fig. 8. - J-V characteristics under illumination of the $\mathrm{CdS}-\left(\mathrm{CHI}_{y}\right)_{x}$ cell (surface $\left.0.1 \mathrm{~cm}^{2}\right)$. 
at $25^{\circ} \mathrm{C}$, in these two cases, the open circuit voltage ranges around $300 \mathrm{mV}$.

The short circuit current density very low for undoped cells $\left(J_{\mathrm{cc}} \approx 20 \mu \mathrm{A} \cdot \mathrm{cm}^{-2}\right)$ is certainly due to the thigh series resistance of the polyacetylene. When doping the current density strongly increases and typically reaches 2 or $3 \mathrm{~mA} . \mathrm{cm}^{-2}$, that is to say about two orders of magnitude higher than in the previous case.

\section{Conclusion.}

The actually highest solar photovoltaic efficiency, $\eta \approx 0.5$ percent, we have obtained for a thin film organic device based on doped $(\mathrm{CH})_{x}$ can be improved by the optimization of the fill factor (actually $F F=0.4$ ) of the cell and by using doped material with improved morphology. This morphology depends strongly of the doping specie and the doping process.

This work is supplied by contrat of the PIRSEM (France)

\section{References}

[1] Tani, T., Grant, P. M., Gill, W. D. et al., Solid State Commun. 33 (1980) 499.

[2] Ozaki, M., Peebles, D., Weinberger, B. R., Heeger, A. J. and MaC Diarmid, A. G., J. Appl. Phys. 51 (1980) 4252.

[3] Kanicki, J., Thèse, Bruxelles (1981).
[4] Ozakgi, M., Peebles, D. L., Weinberger, B. R., Chiang, C. K. Gau, S. C., Heeger, A. J. and Mac Diarmid, A. G., Appl. Phys. Lett. 35 (1979) 83.

[5] Ito, T., Shirakawa, M., Ikeda, S., J. Polym. Sci. Chem. Educ. 12 (1974) 11.

[6] Rolland, M., Cadene, M., Bresse, J. F. et al., J. Microsc. Spectrosc. Electron. 7 (1982) 21. 